\title{
Map and Illustrations
}

1. Select Merovingian-period cemeteries in Gaul and on its frontiers

\section{ILLUSTRATIONS}

1. Chart disproving the alleged transition from golden bees found in Childeric's grave to the Bourbon fleur-de-lys

2. Nineteenth-century model of the development of religious architecture in France

3. Typological chart of earrings and rings for the purpose of establishing their relative chronology

4. Early archaeologist Émile Socley with finds at Noiron-sousGevrey (Côte-d'Or)

5. Glass serving vessels excavated at Herpes (Charente)

6. Beads, ring, brooch, earrings, pin, and hanging tools attributed by $C$. Boulanger to the seventh or eighth century

7. An assemblage of goods in their original position in a GalloRoman warrior's grave at Monceau-le-Neuf

8. Boulanger's idealization of male and female Frankish burials in the fifth and sixth centuries

9. Boulanger's interpretation of the evolution of Frankish interment customs for men and women in the seventh and eighth centuries

10. Face of the Wittislingen brooch, seventh century 
11. Underside of the Wittislingen brooch, with an inscription dedicated to Uffila, presumably the woman with whom it was buried

12. Face of filigree bossed disk brooch discovered at the cemetery of Hermes (Oise), seventh century

13. Backside of disk brooch shown in figure 12, with label showing cemeterial provenance and year of discovery

14. Row grave cemetery of Köln-Müngersdorf

15. Row grave cemetery of Frénouville (Calvados)

16. Two belt buckles and counter-plaques from the Merovingianperiod cemetery of Marchélepot (Somme), dated to the seventh or eighth century by Boulanger

17. Merovingian bronze belt plaque-buckle, from the cemetery of Tabariane (Ariège), seventh century

18. Four chatelaines of unknown provenance depicting a horse and rider, and belt buckle found at Hermes (Oise), with the inscription "Va(le)at qui fecit" or "Vivat qui fecit"

19. Restored grave goods from grave 319 at Lavoye (Meuse), attributed to a Frankish chieftain

20. Artifacts from a Merovingian grave discovered at Saint-Denis, possibly belonging to an elite male

21. Row grave cemetery of Audun-le-Tiche (Moselle)

22. Necropolis of Basel-Bernerring 